\title{
ZAGADNIENIE TZW. GRODÓW KULTOWYCH NA WCZESNOŚREDNIOWIECZNYM POMORZU
}

\author{
THE SO-CALLED CULT GORDS \\ IN EARLY MEDIEVAL POMERANIA
}

\begin{abstract}
The major research issue to which this article is devoted is the identification and presence of settlement structures in Pomerania, referred to in archaeological literature as cult gords. The construction features and excavated sources, registered in areas enclosed with a ring of ramparts, have been characterised in the article as they can undermine the settlement or military functions of the gords. This is corroborated by a poorly preserved cultural layer (or lack thereof) and presence of artefacts and/or historical objects which would indicate a temporary (thus non-utilitarian) nature of the human groups' stay. The predetermined criteria were observed in more than a dozen Pomeranian gords, subjected to a possibly detailed analysis. As a result, further observations were made which allow to hypothetically include some of the surveyed gords to the group of facilities which may pertain to satisfying needs related to cults and rituals.
\end{abstract}

Keywords: early Middle Ages, Pomerania, space organization, cult gords.

Jednym z głównych problemów badawczych, jakim poświęcał uwagę Profesor Władysław Łosiński, były zagadnienia dotyczące osadnictwa i krystalizacji wczesnośredniowiecznych mikroregionów Pomorza. Zasadniczą rolę pełniły tutaj kwestie początków i rozwoju tej formy osiedla, jakim były grody. Obok problematyki dotyczącej sposobu ich konstrukcji, położenia w przestrzeni geograficzno-kulturowej W. Łosiński dużą wagę przywiązywał do prób ustalenia przeznaczenia omawianych struktur. Badacz ten, uwypuklając funkcje mieszkalne, refugialne, rezydencjalne i gospodarczo-rzemieślnicze, niejako mimochodem, na marginesie głównej osi zainteresowan, dotykał zagadnienia ich roli w światopoglądzie symbolicznym i ideologicznym (Bardy, Świelubie, Lubiechowo, Białogard, Kołobrzeg). Wynikało to zapewne ze stanu badań nad tym zagadnieniem, przede wszystkim zaś współczesnemu mu zakresowi rozpoznania wykopaliskowego pomorskich

${ }^{*}$ Muzeum Zachodniokaszubskie w Bytowie, ul. Zamkowa 2, 77-100 Bytów, e-mail: kamilkajkowski@wp.pl. 
obiektów obronnych. Zwrócił przy tym również uwagę na problem dominujących dawniej w archeologii metod interpretacyjnych, w których pomijano kierunki poszukiwań skoncentrowane na roli czynników symbolicznych $\mathrm{w}$ funkcjonowaniu wspólnot wczesnośredniowiecznych (Łosiński 2008, s. 56).

Niestety, obecnie problem ten tylko pozornie prezentuje się w lepszym świetle. W przypadku większości założeń grodowych na Pomorzu wciąż dysponujemy ograniczoną bazą źródłową opierającą się na wynikach starszych prac wykopaliskowych (wielokrotnie sprowadzających się do prospekcji powierzchniowych) lub mało reprezentatywnych badań sondażowych. Wydaje się jednak, że współczesne tendencje badawcze polegające na szerszym ujęciu interdyscyplinarnym i porównawczym, wprzęgające do dyskusji nad interesującym nas zagadnieniem takie dyscypliny humanistyki, jak antropologia kulturowa, antropologia historyczna, religioznawstwo, a w końcu krystalizującą się od 2. połowy minionego stulecia archeologię religii, pozwalają sygnalizowany problem rozpatrywać z szerszej perspektywy.

Już na wstępie podjętych rozważań należy podkreślić, że w literaturze archeologicznej brak jest powszechnie akceptowanej definicji struktur przestrzennych w postaci grodów. Dzięki badaniom językoznawczym wiemy, że słowo gord, pojawiające się w różnych wariantach w większości języków słowiańskich, ma oznaczać tyle, co miejsce ogrodzone (wyodrębnione). Jednak - jak to określił Wojciech Szymański (2015, s. 33) - z takiego stwierdzenia niewiele dla nas archeologów wynika, gdyż poza możliwością określenia prasłowiańskiej genezy tego słowa nic więcej na temat fenomenu wznoszenia grodów powiedzieć się nie da. Powoduje to, że nadal nie wiemy, jakie cechy miałyby charakteryzować takie konstrukcje. Można jedynie stwierdzić, że etymologia słowa 'gród' może wskazywać, iż pierwotnie określenie to mogło odnosić się do wyizolowanej z otoczenia przestrzeni zamkniętej jakąś formą ogrodzenia, niekoniecznie o militarnym przeznaczeniu (Hensel 1948, s. 17; Urbańczyk 2014, s. 27; Szymański 2015, s. 35).

Według opinii W. Losińskiego (1972) około VII w. na niektórych obszarach Pomorza Zachodniego doszło do względnej stabilizacji osadniczej, która miała zapoczątkować proces krystalizacji nowego modelu organizacji życia społeczno-gospodarczego lokalnych wspólnot. Wynikiem tego procesu było pojawienie się obwarowanych osiedli wznoszonych w celu gwarancji bezpieczeństwa tworzących je grup ludności. Tak wczesna chronologia struktur grodowych na obszarze Słowiańszczyzny Zachodniej została jednak poddana krytyce. $Z$ jednej bowiem strony wskazuje się na brak jakichkolwiek informacji na temat obwarowanych osiedli w najstarszych (VI/VII w.) źródłach historycznych (Szymański 2015, s. 32), z drugiej podważają ją ostatnie ustalenia związane $\mathrm{z}$ datowaniem dendrochronologicznym, które znacznie odmładzają czas budowy zdecydowanej większości grodów, odnosząc je do przełomu VIII i IX w. lub raczej początku IX stulecia (Dulinicz 2001, s. 186). Problem ten nie dotyczy jednak datowanych na najwcześniejsze fazy wczesnego średniowiecza obiektów „typu Szeligi” znanych przede wszystkim z obszaru położonego między Wisłą a Dnieprem, którym najczęściej przypisuje się rolę 
ośrodków symbolicznych lub/i ceremonialnych. Na obszarze dzisiejszej Polski wskazuje się tutaj przede wszystkim na niewielkie pod względem powierzchni 'reperowe' obiekty w Szeligach i Haćkach, dla których wprowadzono w literaturze odrębne określenie 'grodu kultowego' (por. Buko 2012, s. 339).

Niewielkimi rozmiarami $(0,1$ do 0,5 ha) charakteryzowały się również najstarsze obiekty grodowe znane z obszaru Pomorza. W. Łosiński (1972) podkreślał również tę ich cechę, jaką były znikome walory obronne. Pojawiające się we wnętrzu niektórych obiektów ślady osadnicze badacz ten uznał za relikty zabudowy mieszkalnej i rzemieślniczo-gospodarczej, co w jego opinii mogło poświadczać stałą obecność użytkujących je grup ludzkich. W takim rozumieniu miały to być ośrodki osadnicze niewielkich terytoriów o areale około $30 \mathrm{~km}^{2}$ tożsame ze wzmiankowanymi przez Geografa Bawarskiego civitates. Tym samym uznał je za samodzielne i niezależne ośrodki polityczne, które były fundamentem pod kształtującą się powoli jednostkę osadniczą określaną w dawniejszej literaturze jako 'małe plemię'.

Ustalenia te krytyce poddał między innymi Przemysław Urbańczyk, wskazując, że ,archeologiczna kartografia ziem polskich nie wykazuje żadnej korelacji z mapami 'plemiennymi' konstruowanymi przez historyków na podstawie źródeł tak enigmatycznych, jak tzw. Geograf Bawarski, czy Dokument praski”. Badacz ten zauważa, że co prawda można mówić o istnieniu w tym czasie jakichś wspólnot terytorialnych, nie oznacza to jednak, że należy im przypisywać cechy świadomych organizacji politycznych. Tym samym wielkość jednostki terytorialnej nie byłaby wynikiem czynników społeczno-ekonomicznych, lecz układu sił determinującym sytuację na określonym obszarze (Urbańczyk 2013, s. 320-321; Biermann 2015, s. 45). W związku z tym budowa grodu poświadczałaby przede wszystkim pozycję wspólnoty w określonym mikroregionie osadniczym, tworząc czytelny punkt fizycznie i symbolicznie legitymizujący prawo do posiadanych do niego praw.

Powyższe spostrzeżenia doprowadziły do intensyfikacji dyskusji na temat funkcji, jaką grody mogły pełnić w życiu wczesnośredniowiecznych społeczności zachodniosłowiańskich. I mimo że zdecydowana większość badaczy nadal skłonna jest odnosić ją do militarno-społecznej gałęzi aktywności ówczesnych grup ludzkich, uznając je za siedziby lokalnej władzy lub rzadziej za obiekty o charakterze refugialnym (ostatnio Biermann 2015, s. 45), coraz częściej pojawiają się głosy wskazujące na inne możliwości - przynajmniej w stosunku do niektórych obiektów (np. Brather 2001, s. 132; Rączkowski 2008, s. 149-150; Wiszewski 2012, s. 322; Moździoch 2013, s. 113-114).

Problem ten widoczny jest także w dyskusji dotyczącej budownictwa grodowego Pomorza. Doskonale obrazuje go wypowiedź Marka Dulinicza, który zadał fundamentalne dla nas pytanie „,zy rzeczywiście gród należy automatycznie kojarzyć z siedzibą władcy, skoro: po pierwsze, przez kilka wieków słowiańscy przywódcy obywali się bez grodów; po drugie: z czasem grodów pojawiło się tyle, że nie sposób w każdym widzieć ośrodek władzy?" (Dulinicz 2014, s, 14). Podobne wątp- 
liwości miał dawniej Władysław Łęga, który podpierając się przekazami źródeł pisanych, zwrócił uwagę, że część znanych mu grodzisk z tego obszaru może być charakteryzowana jako miejsca sprawowania praktyk religijnych (Łęga 1929, s. 311 i n.; por. Łosiński 2008, s. 56; Chudziak 2014, s. 27).

Mimo to problem identyfikacji pomorskich 'grodów kultowych' wciąż wydaje się daleki od rozstrzygnięcia i wzbudza ożywione dyskusje. W literaturze przedmiotu podkreśla się, iż takimi założeniami mogły być przede wszystkim najwcześniejsze struktury obwarowane 'umocnieniami' o znikomych walorach obronnych, cechujące się niekiedy słabo czytelną warstwą kulturową czy obecnością obiektów i/lub zabytków, mogącymi wskazywać na czasowy, a w związku z tym nieutylitarny charakter pobytu w ich obrębie grup ludzkich (Kobyliński 1997, s. 110; Urbańczyk 2012, s. 193; por. też: Rębkowski, Kiarszys 2014). Powoduje to, że współcześnie część takich obiektów rejestrowanych w trakcie badań archeologicznych uznaje się za założenia związane z religijno-obrzędową sferą życia badanych społeczności, bądź też redefiniuje się funkcję niektórych grodzisk uznanych wcześniej za relikty struktur o charakterze militarnym (por. Kara 2009, s. 99-100, 139, 208-209; Kolenda 2009, s. 20-21). Uznając założenia tego rodzaju za konstrukcje determinujące osadnictwo określonego mikroregionu (por. Kujawska 2012, tam dalsza literatura), można przypuszczać, iż część z nich nie musiała i zapewne nie pełniła funkcji stricte militarnych. Mogła natomiast manifestować siłę i pozycję wspólnoty terytorialnej, symbolicznie określając jej tożsamość. „W konsekwencji powstał obiekt, który stwarzając wizualny pozór obronności, równocześnie był łatwo dostępny dla wszystkich" (Rączkowski 2008, s. 148-149).

Kwestią kluczową wydają się tutaj spostrzeżenia P. Urbańczyka (2012, s. 315), postulującego potrzebę ujęcia każdego badanego obiektu w kontekście historycznym (miejsce i czas), wraz z którym zmianie mogły ulegać nie tylko potrzeby lokalnych społeczności, ale także funkcje poszczególnych grodów w strukturach organizacyjnych określonych grup ludzkich.

Biorąc pod uwagę spostrzeżenia tego badacza, zastanówmy się, czy można je odnieść do konkretnych obiektów zarejestrowanych na obszarze Pomorza.

Ośrodkiem, któremu przypisuje się znaczenie symboliczno-religijne, był gród w Białogardzie (Cnotliwy 1982; 1999)1. Wydaje się jednak, że impuls do takiej interpretacji wynika $\mathrm{w}$ głównej mierze z ustaleń Jacka Banaszkiewicza dotyczących fragmentu kroniki Anonima, tzw. Galla. Chodzi o passus opisujący wyprawę Bolesława Krzywoustego na Pomorze. W toku narracji padają tu bowiem znamienne słowa, iż Białogard to „środek ziemi pomorskiej” (Gall II, 39). Według J. Banaszkiewicza (1986a s. 445 i n., 463) stwierdzenie to nie wynika z cech fizyczno-

\footnotetext{
${ }^{1}$ Jest to jeden z najstarszych obiektów tego rodzaju znanych z obszaru Pomorza. Niestety wciąż nierozwiązany pozostaje problem bardziej precyzyjnego datowania jego reliktów opartego wyłącznie na analizie materiału ceramicznego. Według W. Łosińskiego (2008, s. 71) gród powstał już w VII w., z kolei M. Dulinicz (2001, s. 236) uważał, że nie mogło to nastąpić szybciej niż u schyłku VIII stulecia.
} 
geograficznych grodu, lecz z pozycji, jaką ośrodek ten zajmował w systemie ideologicznym użytkującej go populacji, pełniąc w istocie rolę centrum mityczno-kultowego. Jak się okazuje, spostrzeżenie to może odnajdować potwierdzenie w wynikach przeprowadzonych w Białogardzie badań wykopaliskowych, gdyż ani rozmiary grodziska (pomniejszane wraz z kolejnymi przebudowami), ani odkryte w jego obrębie relikty nie wskazują na duże znaczenie polityczne tego ośrodka $\mathrm{w}$ tej części Pomorza. W związku z poruszanymi w tym miejscu zagadnieniami uwagę zwraca natomiast lokalizacja grodu w otoczonej bagnami dolinie rzecznej oraz wyraźna izolacja w stosunku do pozostałych stanowisk osadniczych położonych w dorzeczu Parsęty (Łosiński 1972, s. 166; 2008, s. 67). Zarówno wspomniane cechy, centralne położenie grodu w stosunku do sieci osadniczej oraz okalające go masywne umocnienia skłoniły W. Łosińskiego do włączenia grodu w Białogardzie w struktury administracyjne lokalnej władzy, choć badacz nie negował jego roli w sakralnej topografii tej części doliny Parsęty (Łosiński 2008, s. 71).

Kolejnym obiektem zasługującym na uwagę jest stanowisko położone w najbliższym sąsiedztwie wód jeziora Kwiecko (Stare Borne) (Olczak, Siuchniński 1968, s. 109-113). Mikroregion osadniczy funkcjonujący tu we wczesnym średniowieczu miał składać się m.in. z miejsca kultu położonego na wyspie, grodziska zarejestrowanego na pobliskim półwyspie oraz cmentarzyska kurhanowego ulokowanego na wschodnim brzegu jeziora. Chronologię całego kompleksu, na podstawie ustaleń dendrochronologicznych i analizy materiału ceramicznego, określono na IX-X w. (Członkowski 1967, s. 44; Chudziak, Kaźmierczak i Niegowski 2009, s. 385). Dla podjętych w tym miejscu rozważań najbardziej interesująco prezentują się wyniki badań archeologicznych przeprowadzonych na obszarze grodziska (stan. 1). W rezultacie podjętych prac, poza licznymi fragmentami glinianych naczyń, zarejestrowano charakterystyczne układy kamieni (rząd kręgów i kwadratów) o trudnej do sprecyzowania funkcji (pozostałości kurhanów?). W miejscu jednego z kręgów założono wykop badawczy, w którego profilu zarejestrowano jamę paleniskową. Warto również zwrócić uwagę, że ówczesne badania wykopaliskowe nie ujawniły istnienia na wyspie warstwy osadniczej (Członkowski 1967; 1969). Przytoczone obserwacje spowodowały, iż stanowisko uznano za miejsce sprawowania praktyk obrzędowych (Członkowski 1969; Chudziak, Kaźmierczak i Niegowski 2009, s. 265-266). Na potwierdzenie tej interpretacji przywodzi się XIX-wieczne znalezisko kamiennej rzeźby antropomorficznej (o czym niżej) oraz lokalną tradycję upatrującą w tym miejscu ośrodek kultu pogańskiego (Knoop 1926, s. 36-37; por. Łęga 1929, s. 311). W tym kontekście podkreśla się również fakt położenia grodziska w pobliżu rzeki Radwi, której nazwę wywodzi się niekiedy od pie. *rod-, *rad- 'skrobać', 'grzebać'. Źródłosłów ten ma być znamienny dla pewnej liczby miejsc charakteryzowanych w literaturze jako wczesnośredniowieczne ośrodki sprawowania praktyk obrzędowych (Gross Raden, Rad, Radogoszcz, Radola, Radoma, Radvaň, Radzikowo i in.) (por. Słupecki 1994a, s. 53; Slivka 2004, s. 152, tam dalsza dyskusja). 
Być może nie bez znaczenia dla proponowanej interpretacji omawianego obiektu są rezultaty najnowszych badań archeologicznych, na podstawie których ustalono, że zewnętrzna część wału otaczającego gród licowana była przy wykorzystaniu otoczaków (najczęściej granitu i porfiru) (Członkowski 1969, s. 139; Chudziak, Kaźmierczak i Niegowski 2007, s. 263; Chudziak 2015, s. 41). Taka forma konstrukcji ${ }^{2}$, odbijając promienie słoneczne, powodować musiała charakterystyczny efekt świetlny (dodatkowo wzmacniany przez wody jeziora), a dzięki niemu złudzenie luminacji. Niewykluczone, że dzięki temu omawiane struktury mogły włączać się pod względem symbolicznym do obiektów w typie 'białych grodów', konstrukcji odnoszonych do materialnych projekcji mitu kosmogonicznego (por. Detelić i Ilić 2006; Kowalski 2011, s. 16; Szultka 2014, s. 8). Jakkolwiek na tym etapie badań trudno wyjść dalej poza ujęcia hipotetyczne.

Poza reliktami grodu z fosami, dwoma nasypami w formie kopców zamykającym dostęp do tego obiektu od strony wschodniej i zachodniej oraz wspomnianymi poprzecznymi wałami, zarejestrowano tutaj dwie osady i relikty mostu łączącego półwysep z północnym brzegiem jeziora (Skrzypek 1998/1999, s. 171). Wszystkie te obiekty datuje się w przedziale IX-XII/XIII wieku. W trakcie penetracji podwodnej w obrębie przeprawy mostowej nie zarejestrowano materiału ruchomego (Chudziak, Kaźmierczak, Niegowski i Ważny 2009, s. 111). Prawdopodobnie w niedalekiej odległości, w pobliżu grodziska w XIX stuleciu odkryto kamienną rzeźbę określaną w literaturze mianem Belbuk (Skrzypek 1998/1999).

Nie jest wykluczone, że omawiany gród mógł pełnić rolę centrum lokalnego ośrodka osadniczego o przypuszczalnie dużym znaczeniu, kontrolującego szlak wodny od Radwi do ujścia Parsęty, gdzie w obrębie wyodrębnionej części półwyspu synchronicznie $\mathrm{z}$ grodem funkcjonować mogło sanktuarium. Należy jednak zadać pytanie, czy powinno się je lokować w obrębie obwałować grodu, czy w innym miejscu? Na kultowy charakter omawianego stanowiska ma też wskazywać znaleziona nieopodal wspomniana już kamienna rzeźba. Taki pogląd wynika z faktu, iż część badaczy w przypadku charakterystyki idoli odnajdowanych w akwenach wodnych, opierając się przede wszystkim na późnej relacji Długosza (1867, s. 97-98) o topieniu pogańskich bałwanów tuż po chrzcie Mieszka I, w zasadzie jednomyślnie uznaje, że obiekty takie musiały znaleźć się w wodzie właśnie w wyniku działań ewangelizacyjnych.

Kultowej funkcji badacze doszukują się w przypadku grodziska usytuowanego na stoku Rowokołu. Zarejestrowano tutaj relikty niewielkich rozmiarów założenia obwiedzionego wałem ziemnym datowanego na podstawie materiału ceramicznego na IX-XI stulecie. Wewnątrz obwałowań odkryto ślady po paleniskach, otaczających zwartym kręgiem wolny plac pośrodku majdanu. W paleniskach wystąpiły

\footnotetext{
${ }^{2}$ Element konstrukcyjny w postaci kamiennego licowania nie jest oczywiście niczym wyjątkowym w skali zachodniosłowiańskiego wczesnośredniowiecznego budownictwa obronnego, choć na Pomorzu notuje się go relatywnie rzadko (Rębkowski, Kiarszys 2014, s. 106-107).
} 
liczne węgle drzewne, ceramika oraz kości zwierzęce (Filipowiak 1967, s. 10; Gieysztor 1982, s 177).

Niewykluczone, że treści symboliczno-kultowe mogły odnosić się do struktur archeologicznych zarejestrowanych w pobliżu wsi Janiewice. Na łagodnym stoku zalesionej dominanty terenowej, położonej około $0,5 \mathrm{~km}$ od brzegu jeziora Chomiec, znajdował się obszar zamknięty najprawdopodobniej wałem, zachowanym w postaci dwóch równolegle ułożonych fałd ziemnych. Wewnątrz nich odnotowano obecność dużego białego granitoidu otoczonego kręgiem mniejszych kamieni. Podjęte na tym stanowisku sondażowe badania weryfikacyjne nie przyniosły rozwiązania zagadki czasu powstania (określonego ogólnie na wczesne średniowiecze) i funkcji, jaką omawiane założenie mogło pełnić w przeszłości. Wykazano jedynie, że nie zdradza ono cech osadniczych, skutkiem czego wykreślono je z rejestru grodzisk wczesnośredniowiecznych (Olczak, Siuchniński 1971, s. 263-265). Niemniej jednak zarejestrowane na tym stanowisku rozwiązania dotyczące organizacji przestrzeni mogą wskazywać na charakter wynikający z praktyk niezwiązanych ze stałym zasiedleniem. Na marginesie warto dodać, iż hipoteza ta znajduje poparcie w dawnych nazwach miejscowych tego miejsca: Wendenwall, Opferstätte (Olczak, Siuchniński 1971, s. 263-265).

Nieco uwagi warto też poświęcić grodzisku w miejscowości Rarwino. Obiekt zlokalizowany jest na niewielkim wyniesieniu terenowym otoczonym podmokłymi łąkami. Lustracja stanowiska wykazała, że wewnątrz obszaru zamkniętego pierścieniem czytelnych wałów znajduje się kilka kopców ziemnych, które można ostrożnie interpretować jako nasypy kurhanów. Wydaje się to potwierdzać zespół artefaktów znanych z przypadkowego XIX-wiecznego odkrycia (żelazne miecze, ostrogi i inne elementy uzbrojenia). Z kolei $\mathrm{w}$ wyniku prac sondażowych prowadzonych w tym miejscu zarejestrowano ślady spalenizny i zwarty układ kamieni oraz materiał ruchomy (wióry krzemienne, polepa, kość zwierzęca, fragmenty naczyń ceramicznych), na podstawie których chronologię odkrytych struktur ustalono na IX/X w. (Olczak, Siuchniński 1968, s. 25-31). Trudno ocenić, dlaczego badający grodzisko archeolodzy nie uwzględnili w swoim opracowaniu znajdujących się wewnątrz obwałowań nasypów. Niespełna 50 lat temu musiały być one wyraźnie widoczne $\mathrm{w}$ terenie $\mathrm{i}$, co ciekawe, przynamniej jeden został zaznaczony na opublikowanym planie stanowiska (Olczak, Siuchniński 1968, s. 27, ryc. 19). Jeżeli rzeczywiście gród w Rarwinie był miejscem chowania zmarłych (lokalnej elity?), jego ewentualną militarną funkcję uznać należy za drugorzędną, a sam obiekt charakteryzować przez pryzmat mityczno-religijnej waloryzacji przestrzeni.

Podobną sytuację zaobserwować można w przypadku datowanego na 2. połowę XI-1. połowę XII w. grodziska w Runowie. Na majdanie wyżynnego obiektu jeszcze dziś czytelne są bowiem kopce ziemne dość precyzyjnie umieszczone na opublikowanym planie warstwicowym stanowiska (Olczak, Siuchniński 1985, ryc. 50, wklejka). $Z$ tego samego planu wynika również, że w trakcie akcji weryfikacyjno-wykopaliskowej wykopy sondażowe założone zostały z pominięciem nasypów. 
Trudno ocenić, dlaczego zignorowano ten wyraźnie manifestujący się w otoczeniu element morfologii badanego obszaru.

$\mathrm{W}$ trakcie prac archeologicznych przeprowadzonych na majdanie grodziska wydobyto jedynie nieco ponad 300 fragmentów mało charakterystycznych naczyń ceramicznych, bryłki polepy, węgle drzewne, nieokreślony przedmiot żelazny i najprawdopodobniej bryłkę stopionego szkła. Brak było na tym obiekcie czytelnej warstwy kulturowej, co wraz z widocznymi na majdanie kopcami oraz specyfiką pozyskanego inwentarza zdaje się wskazywać na inny niż osadniczy czy obronny charakter tego miejsca. Pomijając nietypowy, wydłużony kształt grodziska, dodatkową przesłanką za taką interpretacją mogą być również zaobserwowane od wschodu, zachodu i południa przerwy w ciągłości linii wału. Według ustaleń autorów opracowania wyników badań tego miejsca, mogą to być relikty bram prowadzących do jego wnętrza (Olczak, Siuchniński 1985, s. 90-100). Takie rozwiązanie niewątpliwie pomniejszałoby walory obronne konstrukcji fortyfikacyjnych ${ }^{3}$.

Wydaje się więc, że gród w Runowie mógł stanowić element bardziej rozbudowanego kompleksu ideologiczno-osadniczego. Już autorzy opracowania tego stanowiska odnotowali w jego pobliżu pozostałości bezpośrednio przylegającej do niego od południa osady oraz położonego za nią cmentarzyska kurhanowego ${ }^{4}$. Informacje te można uzupełnić o kolejne spostrzeżenia. Okazuje się bowiem, że w pradolinie Pogorzelicy, na zakolu pierwotnej linii rzeki przy jej dawnym brzegu, około $200 \mathrm{~m}$ na północny zachód widoczne są nasypy sporych rozmiarów kurhanów, natomiast $\mathrm{w}$ dolinie tej rzeki $\mathrm{w}$ odległości około 1,4 km w kierunku północno-wschodnim od grodziska znajdują się relikty dawnej zabudowy w postaci pozostałości potężnego wału (lub rowu) najprawdopodobniej kolejnego ${ }^{5}$ grodu o zachowanej powierzchni około $220 \times 130 \mathrm{~m}$. Do momentu rozpoznania archeologicznego nie można z całą pewnością potwierdzić wczesnośredniowiecznej chronologii tych obiektów. Gdyby jednak tak było, mielibyśmy do czynienia z sytuacją odnotowaną w innych częściach Pomorza, wpisującą się w model synchronicznych czasowo struktur dwugrodowych o zróżnicowanych funkcjach (por. niżej).

Możliwe, że podobną rolę mógł odgrywać gród w Kurowie. Obiekt usytuowano na północnym skraju wysokiego wzniesienia i obwiedziono masywnym wałem o stromych stokach. Dodatkowo w części południowo-zachodniej uchwycono nieckowate zagłębienie ostrożnie interpretowane jako pozostałości fosy oddzielającej

\footnotetext{
${ }^{3}$ Podobne do zastosowanego w Runowie rozwiązanie konstrukcyjno-komunikacyjne zaobserwowano w trakcie badań sondażowych na grodzisku w Gołczewie. Do położonego na wyniesieniu terenowym wśród podmokłych łąk grodu obwiedzionego wysokim i szerokim wałem mogły bowiem prowadzić trzy bramy. Z prac archeologicznych pochodzi nieliczny materiał ceramiczny datowany na IX w. Zaobserwowano również brak śladów intensywnego użytkowania obiektu (Olczak, Siuchniński 1989, s. 48-53).

${ }^{4}$ Przyjmując symboliczny charakter omawianego stanowiska, należy postawić pytanie o funkcję 'osady' położonej dokładnie pomiędzy grodziskiem i cmentarzyskiem.

${ }^{5}$ Niebadanego dotąd i nieznanego z literatury.
} 
obiekt od pozostałej części wzniesienia. Na podstawie materiału ceramicznego stanowisko wydatowano na VIII-X w. (Olczak, Siuchniński 1968, s. 88-94). Cechy omawianego grodziska wyraźnie wskazują na jego potencjalną funkcję militarną, jednak pewne wątpliwości wzbudza jego położenie. Okazuje się bowiem, iż od strony południowej, w niewielkiej odległości od niego, znajduje się wysokie, górujące nad grodziskiem wzgórze. W tym kontekście zastanawia, dlaczego obiekt obronny wzniesiono poniżej dominanty terenowej, z której z łatwością można go było ostrzelać i w konsekwencji zdobyć? Wydaje się więc, iż powodu takiego usytuowania szukać należy gdzie indziej. Być może pewną wskazówką mogą być w tym przypadku kopczykowate obiekty (kurhany?) do dziś jeszcze czytelne na majdanie grodu. Niestety, przeprowadzone na tym stanowisku sondażowe badania archeologiczne nie dają podstaw do dalszej dyskusji na temat funkcji, jaką mógł spełniać w okresie wczesnego średniowiecza.

Sugestie odnoszące się do funkcji pozautylitarnej czyni się także w stosunku do grodziska zlokalizowanego we Wrześnicy (Niesyty, Hoppel 1998, s. 170; Rączkowski 2008, s. 148-149). Obiekt ten, położony bezpośrednio na zachód od koryta Wieprzy, otoczony był podmokłymi łąkami. W wyniku badań wykopaliskowych udało się określić dwie fazy zasiedlenia tego miejsca. Z punktu widzenia niniejszych rozważań najistotniejsza jest pierwsza $\mathrm{z}$ nich ${ }^{6}$, z którą wiązać należy pozostałości otoczonego fosą wału drewniano-ziemnego oraz relikty budynków znajdujących się pierwotnie na majdanie. W najbliższym sąsiedztwie obecnego brzegu rzeki odnotowano obecność mostu lub pomostu, ślady faszyny wzmacniającej brzeg i fragment prowadzącej do bramy, moszczonej drewnem drogi. W niedalekiej okolicy przeprawy znaleziono zalegający w torfie skórzany mieszek wypełniony zawartością mogącą wskazywać na możliwość funkcjonowania przy grodzie miejsca targowego ${ }^{7}$. Chronologię odkrytych pozostałości na podstawie wyników datowania dendrochronologicznego określono na schyłek IX w. (Rączkowski 1998, s. 160). W wyniku ich analizy wątpliwości niektórych badaczy zaczęła wzbudzać obronna funkcja grodu (Niesyty, Hoppel 1998, s. 170; Rączkowski 2008, s. 148-149). Okazuje się bowiem, że pomiędzy podstawą wału a znajdującym się na przedwalu zasiekiem zarejestrowano obecność biegnącej wzdłuż całości obwarowań konstrukcję wykonaną z plecionki, która ułatwiała dostęp do obszaru znajdującego się wewnątrz umocnień. Takie rozwiązanie architektoniczne generuje pytanie o ,militarną wartość zarówno zasieku, jak i w pewnym przynajmniej stopniu wału" (Niesyty, Hoppel 1998, s. 170). Podobne wątpliwości wzbudza rola 'fosy', gdyż w wyniku analiz wypełniających ją nawarstwień nie potwierdziło się przypuszczenie, że w trakcie użytkowania grodu była ona wypełniona wodą. Co

${ }^{6}$ Młodsza faza osadnictwa związana była z osadą otwartą powstałą w tym miejscu po pożarze grodu.

719 odważników, 9 prętów, 3 okucia, 2 półfabrykaty paciorków bursztynowych oraz fragment siekańca. 
więcej okazuje się, że w tym czasie jej dno porastały już kępy turzyc (Rączkowski 2008, s. 147-148). Wiele wskazuje więc na to, iż funkcję omawianego obiektu łączyć należałoby z innym niż obronne przeznaczeniem.

Ciekawym uzupełnieniem powyższych wniosków są wyniki obserwacji poczynionych na podstawie metody viewshed analysis. Charakterystyce poddano grodzisko wraz $\mathrm{z}$ najbliższym zapleczem osadniczym. Okazało się, że $\mathrm{z}$ grodu rozpościera się widok na niemal wszystkie okoliczne osady otwarte i cmentarzyska kurhanowe (Rączkowski 2008, s. 148-149). Wszystko to powoduje, że w literaturze przedmiotu obiekt we Wrześnicy uznaje się za „centralny ośrodek jednego z mikroregionów osadniczych na Pomorzu Środkowym" (Niesyty, Hoppel 1998, s. 170; Rączkowski 2008).

W korpus analizowanych struktur architektonicznych włącza się także niekiedy grodzisko w miejscowości Brody. Obiekt ten, usytuowany na skraju wysoczyzny na wydzielonym pagórku, badany był wykopaliskowo w niewielkim tylko zakresie. W wyniku przeprowadzonych poszukiwań powierzchniowych i sondażowych ustalono, że posiadająca niewielkie walory obronne konstrukcja wałów zamykała majdan o znikomej warstwie kulturowej wydatowanej na podstawie analizy ceramiki naczyniowej na VII-VIII w. (Cnotliwy, Nawrolski 1979, s. 161-167). Ograniczony zakres rozpoznania archeologicznego nie daje podstaw do wysuwania bardziej szczegółowych wniosków na temat ewentualnej funkcji, jaką gród w Brodach mógł spełniać w początkowych fazach wczesnego średniowiecza. Niemniej jednak warto odnotować propozycję Eugeniusza Cnotliwego i Tadeusza Nawrolskiego, którzy obiekt ten łączą występującym w źródłach pisanych określeniem tumulos paganorum (PUB I, nr 104) jednocześnie mogącym sugerować jego funkcję 8 .

$\mathrm{Na}$ inną cechę pomorskich grodów, mogącą rzucić nieco światła na próby odczytania intencji ich wznoszenia, zwrócił ostatnio uwagę Wojciech Chudziak. Badacz ten, opierając się na charakterze i rozlokowaniu poszczególnych elementów sieci osadniczej, wskazał na czytelny w przypadku niektórych mikroregionów Pomorza układ, w skład którego wchodziły pary synchronicznych pod względem chronologicznym grodów położonych od siebie w niewielkiej odległości. Wskazując na brak uzasadnienia interpretowania ich w podobnych kategoriach funkcjonalnych, uznał, że pierwotnie musiały one pełnić odmienną rolę związaną z podziałem przestrzeni i jej organizacją (Chudziak 2014, s. 27)9. Proponowana hipoteza oparta została na analizie wyników badań archeologicznych między innymi ośrodków w Bobięcinie i Radaczu. Należy więc poświęcić im nieco uwagi.

Stanowisko położone w centralnej części wyspy Jeziora Bobięcińskiego wchodziło w ramy terytorialne zespołu osadniczego składającego się z grodziska dato-

${ }^{8}$ Z kolei Ryszard Kiersnowski (1955b, s. 123-125) zapis ten uznał za termin określający 'groby pogan' i łączył z nasypami kurhanów położonych na północ od wsi Brody.

${ }_{9}$ Warto w tym miejscu zasygnalizować, że omawiany problem jest szerszy i nie dotyczy tylko grodów, ale generalnie tzw. miejsc centralnych. 
wanego na 2. połowę X-XI w. wraz z prowadzącym do niego mostem (którego chronologię na podstawie badań dendrochronologicznych określono na XI stulecie) oraz przylegającej do niego od strony południowej osady podgrodowej. Na pobliskim półwyspie zarejestrowano relikty kolejnego grodu (Świerczewo, stan. 1). $\mathrm{W}$ rezultacie prac wykopaliskowych ustalono, że ten ostatni obwiedziony był wałami kamienno-ziemnymi o niewielkich walorach obronnych i najpewniej nie pełnił funkcji związanych ze stałym pobytem grup ludzkich. $\mathrm{Na}$ podstawie analizy materiału ceramicznego chronologię jego użytkowania określono na 2. połowę XI-1. połowę XII w. (Kaźmierczak, Kowalewska i Niegowski 2011, s. 467-468; Chudziak 2014, s. 28). Na symboliczne znaczenie tego miejsca ma też wskazywać pozyskany z wód otaczającego go jeziora materiał ruchomy (ceramika naczyniowa, grudki polepy, kości zwierzęce, pojedyncze przedmioty metalowe w tym zespół militariów, dłubanka) (Kola, Wilke 2006, s. 156-160), łączony z aktywnością obrzędową lokalnych społeczności (Chudziak 2014, s. 24).

W okolicach jeziora Radacz, w wyniku poszukiwań archeologicznych, odkryto dwa grodziska, których funkcjonowanie chronologicznie częściowo się pokrywa. Pierwsze z nich zarejestrowano na północnym brzegu jeziora, drugie (domniemane) oddalone jest około $1 \mathrm{~km}$ i położone na kilkumetrowym wyniesieniu wśród podmokłych łąk, co wydaje się wskazywać, że w przeszłości była to wyspa połączona $\mathrm{z}$ suchym lądem (zarejestrowaną w trakcie badań podwodnych) przeprawą mostową. W obrębie tego obiektu odkryto występujące bezpośrednio pod współczesnym humusem duże palenisko zbudowane z kamieni polnych. Omawiane wyniesienie otoczone było koncentrycznym drewnianym wałem wzniesionym w konstrukcji przekładkowej. Wykonane pomiary radiowęglowe pozwoliły na synchronizację tej konstrukcji z mostem (IX/X w.). W wyniku analizy zebranych informacji postawiono tezę, iż działalność osadniczą lokalnej społeczności należy wiązać z pierwszym grodziskiem, natomiast drugie interpretuje się w optyce myślenia symbolicznego (Chudziak, Kaźmierczak, Niegowski i Ważny 2009, s. 122).

Analiza wyników badań wykopaliskowych pozwala stwierdzić, że zbliżonych zależności chronologicznych między strukturami grodowymi jest na Pomorzu znacznie więcej ${ }^{10}$. Problem jednak w tym, że opublikowany dotychczas zakres roz-

${ }^{10}$ Być może do zaproponowanego modelu można odnieść charakteryzowane wyżej stanowisko w Runowie oraz grodzisko w Parsowie. W tym drugim przypadku wyróżniono położone w niewielkiej odległości od siebie dwa obiekty, z których jeden (stan. 6) uznać należy za pozostałości grodu, natomiast skromny zakres prac wykopaliskowych nie pozwolił na bardziej precyzyjne ustalenia dotyczące drugiego z nich (stan. 7). Autorzy badań nie przeceniają, czy mamy do czynienia z reliktami osady, czy też obiektu otoczonego wałem. Na podstawie analizy zebranego materiału ceramicznego ustalono synchroniczną chronologię dla obu stanowisk - kolejno na VII i VIII (może połowę IX) i VIII-X w. (Cnotliwy, Nawrolski 1979, s. 197-198). Podobną interpretację warto rozważyć dla mikroregionu w Brześciu, pow. szczecinecki. Na niewielkim obszarze znajdują się tutaj relikty trzech grodzisk. Na dwóch z nich (stan. 1, stan. 3) odnotowano dość intensywną warstwę kulturową, na trzecim (stan. 2) w zasadzie jej nie stwierdzono. Dwa (stan. 2, stan. 3) leżą na brzegach (półwyspach) tego samego jeziora w odległości zaledwie 200 m (Olczak, Siuchniński 1970, s. 9-22). 
poznania archeologicznego nie daje podstaw do wyciągnięcia jakichkolwiek wniosków na temat zachodzących między nimi relacji funkcjonalnych.

$\mathrm{Na}$ podstawie dotychczasowych ustaleń W. Chudziaka, opartych na relatywnie niewielkiej liczbie stanowisk, trudno też przesądzać o zasadności zastosowania proponowanej przez tego badacza hipotezy dla obszaru całego Pomorza czy też, jak wskazuje jej autor, odnosić do strefy Słowiańszczyzny Zachodniej w ogóle (Chudziak 2014, s. 54). Niewątpliwie wymaga ona dalszych szczegółowych badań. Niemniej jednak warto w tym miejscu odnieść się do ustaleń historyków wykazujących, że z reguły główny ośrodek polityczny określonego mikroregionu osadniczego lokowany był $\mathrm{w}$ najbliższym otoczeniu centrum religijno-obrzędowego badanej wspólnoty (por. Deptuła 2001, s. 7), a jego zawłaszczenie było często jednoznaczne $\mathrm{z}$ ukonstytuowanym religijnie panowaniem nad całym związanym $\mathrm{z}$ nią dominium. Ustalenia te odnajdują potwierdzenie w wynikach badań Michała Kary (2009) dla obszaru Wielkopolski. Podobne stanowisko zajmują badacze czescy, wskazując na zbliżony model aktywności polityczno-ideologicznej na tym terytorium w interesującym nas czasie (Dostal 1975, s. 104-110; Klanica 1986; Boháčova, Frolík 1991, s. 564-568; Frolík, Smetánka 1997, s. 51-55; Třeštík 1997, s. 339-340). Stąd też, mimo zasygnalizowanych wyżej wątpliwości, nie można wykluczyć ich zasadności dla innych części wczesnośredniowiecznej Słowiańszczyzny Zachodniej.

W kontekście analizowanej problematyki nie bez znaczenia może być również spostrzeżenie, iż zachowane relikty konstrukcyjne wskazują, że cechą charakterystyczną większości pomorskich grodów był zamysł wznoszenia ich na planie bardziej lub mniej regularnego owalu. Warto w tym miejscu odwołać się do ustaleń religioznawców, według których w wierzeniach wielu kultur koło uważano za najdoskonalszą formę geometryczną, odzwierciedlając akt tworzenia kosmosu (Lurker 1972; Margul 1987; por. Kowalski 2011, s. 23), a ruch po okręgu za wyjątkowo skuteczny w kontaktach ze sferą nadprzyrodzoną (Mencej 2013). Symbolika ta wydaje się także znajdować odzwierciedlenie w badaniach nad kulturą dawnych Słowian. Według ustaleń językoznawców, zarówno świat, jak i zamieszkujących go ludzi określano mianem obъtjo, z którego pochodzić mają słowa ros. общчина, pol. obcy i obъljъ 'obły', 'okrągły' w znaczeniu całkowity. W rezultacie może to wskazywać na 'implikacje demiurgiczne' związane z aktem tworzenia obejścia, czyli „obszaru, który się obchodzi wokół, który jest ważny, bo komuś na nim zależy, czyli 'kogoś obchodzi' i ma walor niemal świętości, ponieważ tam spełnia się obchody, polegające na okazywaniu czci i świętowania (...) a zatem siedziby mającej kształt okręgu" (Kowalski 2013, s. 130).

Koresponduje to z symbolicznymi znaczeniami, jakie przypisuje się aktom budowania różnorodnych struktur, mającymi być ziemskim odzwierciedleniem aktu kreacji świata. Akty te mogły być konstytuowane rozmaitymi formami czynności obrzędowych inicjowanymi już od momentu wyznaczenia miejsca pod budowę (Adamczewski 2005, s. 69). Według niektórych badaczy bezpośrednim potwierdze- 
niem takich działań dokonywanych przez Słowian Zachodnich może być passus znajdujący się w relacji Ibrahima ibn Jakuba opisującego sposób wytyczania przez pogan obszarów pod budowę struktur osadniczych ${ }^{11}$. W związku z tym treści symboliczne przypisuje się już samej formie grodów, wskazując, iż taki a nie inny sposób konstrukcji może być odbierany jako rodzaj „,religijnej nobilitacji przestrzeni" (Margul 1987, s. 41) ${ }^{12}$.

Przekazy mityczne dotyczące legend dynastycznych Czech, Polski czy Rusi (Banaszkiewicz 1986; Golema 2007), źródła kościelne oraz etnograficzne (np. Gołębiowski 1830, s. 143; Ciszewski 1903, s. 60) wskazują na inne jeszcze warianty charakteryzowanych aktów: rytualną orkę/oborywanie, okrążanie i okadzanie. Nie ulega wątpliwości, że większość z opisywanych działań nie pozostawiła śladów materialnych, w związku z czym nie może mieć odbicia w materiałach pozyskiwanych w wyniku badań archeologicznych. Jedynymi czynnościami możliwymi do weryfikacji metodami wykopaliskowymi są relikty rytualnej orki i oczyszczania gruntu ogniem. Te pierwsze rejestruje się jednak wyjątkowo rzadko i głównie w obrębie obszarów nekropolicznych. Niemniej jednak z obszaru wczesnośredniowiecznego Pomorza, poza dwoma domniemanymi przypadkami ${ }^{13}$, tego typu pozostałości nie są mi znane. Podobnie rysuje się sytuacja dotycząca adaptacji przestrzeni hierofanicznych i budowy struktur przestrzennych w postaci grodów.

Na możliwość realizacji czynności symbolicznych związanych z puryzacją ogniem wskazują wyniki prac archeologicznych przeprowadzonych na grodzisku w Bardach, gdzie zarejestrowano relikty w postaci warstw spalenizny i popiołów uchwyconych ,powyżej gliniastej podstawy jądra umocnień” (Łosiński 1972, przyp. na s. 130). Niewykluczone, że podobnych śladów można domyślać się na innych

11 „Udają się umyślnie na łąki obfitujące w wodę i zarośla, po czym kreślą tam linię kolistą lub czworoboczną, w miarę tego jaki chcą mieć kształt grodu i obszar jego powierzchni”. Trudno zgadywać, co autor miał na myśli i co w zasadzie może oznaczać kreślenie linii. Być może chodzi tutaj o akt oborywania (o czym niżej). Relacja Ibrahima ibn Jakuba dotycząca obierania miejsca pod gród nie musi oczywiście dotyczyć kwestii religijnej. W podobny bowiem sposób wyznaczano granice obszarów zurbanizowanych w okresie średniowiecza.

${ }^{12} \mathrm{~W}$ związku z powyższym warto też zwrócić uwagę na spostrzeżenia religioznawcy Henryka Swienko (1983, s. 123), według którego „Organizowanie przestrzeni w koła i kręgi dominowało we wszystkich kulturach. Przy grupowaniu się przestrzennym ludzi szczególnym wyróżnieniem cieszy się układ kolisty. Takie bowiem ustawienie pozwala wszystkim uczestnikom grupy zachować względem siebie pozycję zbliżoną do twarzy w twarz. Dokoła każdego człowieka formuje się, w miarę jak konstytuuje się naszą osobowość, taka personalna przestrzeń. Poszczególne osie i kierunki ulegają tu zróżnicowaniu i w związku z tym otrzymują różne wartości. Przód i tył zmieniają swoją pozycję przy obrocie osoby, a nie są jednakowo ważne. To, co jest szczególnie ważne, chcemy mieć przed sobą, to, co jest za nami, staje się niepewne, co więcej - obce.

${ }^{13}$ Mam tutaj na myśli badany w 2015 r. przez archeologów z muzeum w Koszalinie kurhan nr 1 ze stanowiska 17 w Grzybnicy. W trakcie prac nie pozyskano materiału źródłowego, jednak forma pochowku zdaje się wskazywać na wczesnośredniowieczną chronologię (informacja ustna Andrzeja Kuczkowskiego). Niewykluczone, że ślady podobnych działań odkryto także w Jabłończu Wielkim (stan. 1) (Kajkowski, Kuczkowski i Drozd-Lipińska, w druku). 
grodziskach Pomorza ${ }^{14}$. Na ogół charakteryzuje się je jako dowód zniszczenia struktur grodowych, co może wynikać z dawniejszego stanu badań lub subiektywnych interpretacji badaczy. Na podstawie dotychczasowej wiedzy problem ten pozostać musi na razie nierozstrzygnięty.

Spośród kilkuset datowanych na początkowe fazy wczesnego średniowiecza grodzisk znanych z obszaru Pomorza w dziesiątkach liczyć można obiekty charakteryzujące się wyizolowaniem $\mathrm{z}$ otoczenia lub/i znikomą warstwą kulturową (lub jej brakiem). Problem w tym, że pierwszą z nich łączyć można ze specyfiką grodu jako miejsca obronnego, drugą zaś odnosić do skali rozpoznania archeologicznego. W obu przypadkach stan badań nie upoważnia do daleko idących wniosków. Dla omawianego okresu zaledwie trzynaście grodzisk wydaje się mieć związek z symboliczną organizacją przestrzeni: Białogard, Brody, Kurowo, Radacz, Rakowo, Stare Borne, Rarwino, Runowo, Smołdzino (Rowokół), Wrześnica oraz z pewnymi zastrzeżeniami Brześć, Gołczewo i Parsów. Mimo że zakres rozpoznania tych stanowisk pozostawia wiele do życzenia, wydaje się, że odkryte relikty pozwalają na podjęcie próby rekonstrukcji cech morfologicznych związanych $\mathrm{z}$ ich pierwotną zabudową, wyglądem i rolą w organizacji życia religijno-obrzędowego.

Militarnym funkcjom analizowanych konstrukcji przeczy szereg cech stawiających pod znakiem zapytania ich walory defensywne: obecność zbyt szerokich lub kilku bram - szczególnie narażonych w trakcie potencjalnego ataku (Gołczewo, Stare Borne, Wrześnica), czy wznoszenie plecionych konstrukcji ułatwiających dostęp do wnętrza obszaru obwiedzionego wałem (Wrześnica).

Nie wiemy, czy całą wyznaczoną $\mathrm{w}$ ten sposób przestrzeń traktowano jako miejsce wartościowane przez pryzmat czynności religijnych. Analiza wyników badań archeologicznych nie pozwala na zbyt daleko idące wnioski w tym zakresie. Sytuacja zaobserwowana w Radaczu (por. wyżej) wskazuje, iż przynajmniej w niektórych przypadkach tak nie było. Musimy się więc liczyć z możliwością funkcjonowania dodatkowo wyodrębnionych struktur sakralnych. Z relacji źródeł pisanych wynika, że taki sposób organizacji przestrzeni charakteryzował niektóre ośrodki nadmorskie. Były to jednak ośrodki wyjątkowe na mapie wczesnośredniowiecznej Słowiańszczyzny nadbałtyckiej, którym ze względu na istotę ustroju politycznego, a przede wszystkim charakter życia gospodarczego, część badaczy przypisuje funkcję wczesnych (proto-)miast (Łosiński 1988, s.131; Leciejewicz 1989, s. 139). $\mathrm{Z}$ kolei ich stosunek względem zaplecza osadniczego czy funkcjonującego w pobliżu miejsca kultu miał mieć już pewne znamiona wskazujące na krystalizowanie się, charakterystycznych dla tej części wczesnośredniowiecznej Słowiańszczyzny, elementów wczesnopaństwowych (Kurnatowska 1997, s. 30). Odmienna organizacja społeczno-polityczna oraz widoczne różnice w lokalnej przestrzeni osadniczej

14 Na możliwe ślady oczyszczania gruntu pod budowę grodu zwrócono uwagę w przypadku wielkopolskiego Ostrowa Lednickiego (Wrzesiński, Kara 2016, s. 83, 95). Według opinii Jacka Wrzesińskiego i Michała Kary (2016, s. 83): „zabieg taki był często praktykowany przez wczesnośredniowiecznych Słowian podczas budowy grodów”. 
nadmorskich osiedli rzemieślniczo-handlowych mogły mieć wpływ na rozwiązania dotyczącej charakteru i wyglądu miejsc sprawowania czynności religijnych. Co prawda, w niektórych przypadkach można domyślać się funkcjonowania miejsc kultu położonych sub Iove (Szczecin, może Kołobrzeg), jednak z Wolina pochodzą już relikty budynku pełniącego najpewniej funkcję świątyni. Struktur tego rodzaju (przynajmniej jak dotąd) nie znamy z interioru Pomorza, co w kontekście dotychczasowej wiedzy może wskazywać, że taki sposób organizacji przestrzeni kultowo-obrzędowej charakteryzował na tym obszarze wyłącznie ośrodki położone bezpośrednio przy linii brzegowej Bałtyku.

$\mathrm{Na}$ inny jeszcze sposób percepcji obszarów położonych w obrębie wałów grodowych wskazują odkrycia w Rarwinie, Runowie i być może Brodach, Kurowie i Starym Bornym. Zarejestrowane tutaj nasypy domniemanych kurhanów sugerują odmienne znaczenia odbywanych w tych miejscach aktów rytualnych, które odnieść można do obrzędowości funeralnej. Niestety stan badań nad tymi obiektami nie pozwala określić, czy zarejestrowane wewnątrz umocnień mogiły można synchronizować z czasem wzniesienia wałów. Innymi słowy, nie wiemy, czy kurhany usypano na majdanie w tym samym czasie, w którym powstały grody, czy też są one młodsze i powstały już po zatraceniu pierwotnej funkcji fortyfikacji. Bez względu na to, która z powyższych możliwości jest bliższa prawdy, faktem pozostaje, że - jeśli znajdujące się tutaj kopce uznamy za miejsca pochówków - analizowane założenia grodowe (lub ich relikty) odgrywały określoną funkcję w życiu religijnym użytkujących je wspólnot.

Opierając się na dotychczasowym stanie wiedzy, nie możemy również odpowiedzieć na pytanie, których zmarłych i dlaczego chowano w tych miejscach? Jest to o tyle interesujące, że zdecydowana większość cmentarzysk znanych z wczesnego średniowiecza lokalizowana była na obszarach wyłączonych z ekumeny, co może wskazywać na wyjątkową rolę osób pochowanych w przestrzeni zamkniętej wałami grodu.

W związku z powyższymi uwagami wydaje się, że pojęcie grodu kultowego traktować można jedynie umownie i odnosić do miejsc o charakterze wielofunkcyjnym. Miejsc traktowanych jako punkty środka skupiające prerogatywy obszarów prestiżowych i wiecowo-kultowych (por. Łosiński 1972, s. 301) ${ }^{15}$. Związek z tymi ostatnimi nadawał tym obszarom wymiar nie tylko władzodajny, ale przede wszystkim integrujący lokalne wspólnoty i poświadczający mityczne i sakralne prawo do posiadania zajmowanego przez nie terytorium. W takim rozumieniu także wybór obszaru pod budowę grodów nie musiał być tylko konsekwencją uwarunkowań środowiskowych wynikających z ich potencjalnej obronności.

Zresztą obie funkcje nie musiały się wykluczać. Wspominany już, zaproponowany przez M. Karę, model polityczno-ideologicznej organizacji i legitymizacji

$15 \mathrm{~W}$ grodach (lub ich pobliżu), szczególnie tych położonych na linii przebiegu szlaków handlowych, funkcjonować mogły także lokalne place targowe/miejsce wymiany. 
władzy Piastów nad włączonymi do struktur formującego się państwa terenów, zakładał proces zawłaszczania centrów religijnych anektowanych ziem (Kara 2009; Kurnatowska i Kara 2010). W szerszym ujęciu byłby to zatem proces umożliwiający manipulowanie systemem symbolicznym. Proces polegający na oswajaniu sił sakralnych i związany z nowymi realiami społeczno-politycznymi. Wiązałby się on również z przejęciem kontroli nad określonym terytorium i podniesieniem statusu kontrolujących go rodów/wspólnot (por. Dalewski 2001, s. 431).

Dlatego też nie musi dziwić, że obszar uważany za 'punkt środka', konstytuujący byt poszczególnych jednostek terytorialnych, w czasach zaburzeń politycznych przybierał formę obiektu obwarowanego. W sensie myślenia symbolicznego zdobycie takiego miejsca było równoznacznie nie tylko z fizyczną zależnością od zwycięzców, ale również z utratą protekcji czczonych w nim sił sakralnych ${ }^{16}$.

Odrębnym problemem pozostaje proces ewolucji organizacji przestrzeni sakralnych i funkcji, jaką mogły w niej spełniać grody. Analiza dostępnej bazy źródłowej pozwala postawić hipotezę, iż na początkowym etapie rozwoju wyobrażeń religijnych obszary służące mediacji z siłami nadprzyrodzonymi były miejscami 'objawionymi' zlokalizowanymi poza ekumeną. Wraz z rozwojem przestrzeni osadniczej nastąpiła potrzeba oswojenia tych sił, które wprowadzono do zamkniętej przestrzeni planowo zorganizowanej przez człowieka ${ }^{17}$.

W związku z tym najwcześniejsze grody można uznać za związane nie tyle (lub może nie tyle) z potrzebą podkreślenia prestiżu wznoszących je wspólnot, ile wyizolowane $\mathrm{z}$ otoczenia miejscami mityczno-symbolicznymi. Potrzeba obwarowania tych miejsc mogła wynikać $\mathrm{z}$ obawy przed próbą ich zawłaszczenia przez ugrupowania próbujące rozszerzyć własną strefę wpływów. Wraz z rozwojem gospodarczym i demograficznym (VIII-IX w.), którego następstwem było pojawianie się licznych osiedli otwartych, uwidoczniła się potrzeba wznoszenia obiektów obronnych zabezpieczających wpływy krystalizujących się środowisk elitarnych (por. Dulinicz 2001, s. 186). W sensie ideowym byłoby to tożsame z procesem wznoszenia coraz większej liczby konstrukcji o charakterze obronnym, które mogły funkcjonować obok obwarowanych miejsc kultowo-obrzędowych, stanowiąc jednocześnie gallowy środek (jakiejś) ziemi.

W okresie pomiędzy X a schyłkiem XI w. nie obserwujemy wzrostu aktywności związanej ze wznoszeniem obiektów, które można by interpretować jako 'gro-

${ }^{16} \mathrm{~W}$ tym kontekście warto również zwrócić uwagę na nieliczne przykłady wznoszenia grodów w bezpośrednim sąsiedztwie miejsc kultu pogańskiego (Rowokół czy leżące już poza Pomorzem Giecz i Ślęża). Nie można wykluczyć, że konstrukcje te mogły zostać zbudowane m.in. celem ochrony punktów o szczególnej roli w życiu religijnym lokalnych wspólnot.

${ }^{17}$ Nie wiemy, czy 'grody kultowe' wznoszono na miejscu wcześniejszych sanktuariów tzw. typu otwartego, czy też stanowiły zupełnie nową jakość w organizacji przestrzeni sakralnej. Obie formy obszarów kultowych charakteryzowały zbliżone cechy: lokalizacja na wyraźnie dominującym nad okolicą wypiętrzeniu terenowym, w przestrzeni otoczonej wodą (bagnami) i położonej w obrębie gęstych drzewostanów. Na drugą z możliwości może, ale nie musi wskazywać paralelne funkcjonowanie obu rozwiązań czytelne przynajmniej do schyłku XI w. (Kajkowski 2017a). 
dy kultowe'. Niemniej jednak nadal mogły funkcjonować starsze obiekty tego typu (Białogard, Bobięcino/Świerczewo, Rakowo, Runowo) oraz inne miejsca kultu (Kajkowski 2017a, s. 293 i n.). Z badań nad przemianami społeczno-ideologicznymi obszaru Wielkopolski wiemy natomiast, że przestrzenie obrzędowe mogły znajdować się w obrębie dużych grodów identyfikowanych jako centra polityczne (Kara 2009). Możliwe, że podobnych rozwiązań można doszukiwać się również na Pomorzu. Pośrednio wskazuje na to lokalizacja znajdujących się wewnątrz obwarowań grodowych najstarszych świątyń chrześcijańskich, które mogły być wznoszone w miejscu dawnych struktur religijnych (Kajkowski 2017, s. 28 i n., gdzie dalsza dyskusja) ${ }^{18}$.

Podsumowując dotychczasowe uwagi, należy podkreślić, iż sposób konstrukcji oraz położenie niektórych założeń grodowych w topografii określonego mikroregionu wyraźnie wskazują, że nie zawsze o decyzji ich wzniesienia rozstrzygać musiały względy natury politycznej, militarnej czy osadniczej. Ważną rolę odgrywać tutaj mogły także cechy środowiskowe osadzone w perspektywie myślenia mityczno-religijnego, gdzie czynnikiem decydującym o doborze miejsca pod wzniesienie grodu były elementy nadnaturalne (Dulinicz 2000, s. 90; Wielgosz 2006, s. 17, 19). Sytuacja ta znajduje bezpośredni refleks w procesie adaptacji miejsc o szczególnej emanacji sił sakralnych (góry, wyspy), choć najpewniej różniła się pod względem nadawanych tym obszarom sensów ontologicznych. W jednym i drugim przypadku mamy jednak do czynienia z aktem zawłaszczania określonego wycinka przestrzeni i procesem włączania go do świata oswojonego.

\section{LITERATURA}

Adamczewski J. 2005, Młynarstwo magiczne, Wrocław, Polskie Towarzystwo Ludoznawcze.

Banaszkiewicz J. 1986a, Jedność porządku przestrzennego, społecznego i tradycji początków ludu (Uwagi w urzadzeniu wspólnoty plemienno-państwowej u Stowian), Przegląd Historyczny 77/3, ss. 445-466.

- 1986b, Podanie o Piaście i Popielu. Studium porównawcze nad wczesnośredniowiecznymi tradycjami dynastycznymi, Warszawa, Wydawnictwo Naukowe PWN.

Bielowski A. (wyd.) 1872a, Ebbonis vita Ottonis episcopi babenbergensis, w: Monumenta Poloniae Historica. Pomniki dziejowe Polski, t. 2, Lwów, wydane nakładem autora, s. 32-70.

${ }^{18}$ Szczególnie instruktywny wydaje się tutaj przykład Kołobrzegu (por. Łosiński 1972, s. 305), w którym przed podjęciem inicjatyw związanych z erygowaniem biskupstwa słyszymy o potrzebie egzorcyzmowania okolicy i wypędzeniu sił demonicznych (Thietmar VII, 71). Z relacji źródeł pisanych wiemy też, że kościoły wzniesiono na miejscu kultu pogańskiego w Szczecinie (Ebo II, 9) i Wolinie (VP II, 16). Wiadomości te wydają się znajdować potwierdzenie w wynikach prac archeologicznych prowadzonych na Wzgórzu Zamkowym (Wzgórzu Trzygłowa) w pierwszym z tych ośrodków (Słupecki 1994, s. 74; Łosiński 2003, s. 72). W przypadku Wolina problem jest bardziej złożony, odkryte bowiem tutaj relikty interpretowane jako pozostałości kaciny nie odpowiadają lokalizacji znanej z opisu Vita Priefliengensis (dyskusja zob. Kajkowski 2017b). Zbliżonego modelu zawłaszczania i resemantyzacji obszarów pogańskiego sacrum archeolodzy domyślają się również w Kamieniu Pomorskim (Porzeziński, Garczyński 2006, s. 178), Lubiniu (por. Rębkowski 2016, s. 233-234) czy Pyrzycach (Porzeziński 2006, s. 313). 
- 1987b, Monachi Priefliengensis vita Ottonis episcopi babenbergensis, w: Monumenta Poloniae Historica. Pomniki dziejowe Polski, t. 2, Lwów, wydane nakładem autora, s. 128-139.

Biermann F. 2015, Slavic Strongholds South of the Baltic at War, w: R. Atzbach, L.M.S. Jensen i L.P. Lauritsen (red.), Castles at War, Bonn, Dr. Rudolf Habelt Gmbh, s. 39-58.

Boháčova I., Frolík J. 1991, Nové archeologické prameny o počátky pražského hradu, Archeologické Rozhledy 43, s. 562-576.

Brather S. 2001, Archäologie der westlichen Slawen. Siedlung, Wirtschaft und Gesellschaft im früh- und hochmittelalterlichen Ostmitteleuropa, Berlin, Walter De Gruyter.

Buko A. 2012, Główne cezury i wyznaczniki zmian społeczno-kulturowych na ziemiach polskich we wczesnym średniowieczu (zarys problematyki badawczej), w: T. Gralak (red.), Rytm przemian kulturowych w pradziejach i średniowieczu, Biskupin-Wrocław, Wydawnictwo PAN, s. 337-373.

Chudziak W. 2014, Wczesnośredniowieczne osadnictwo Pojezierza Zachodniopomorskiego w najnowszych badaniach ośrodka toruńskiej archeologii - nowe pytania, stare problemy, w: H. Paner, M. Fudziński i W. Świętosławski (red.), Pomorze we wczesnym średniowieczu w świetle źródet archeologicznych. Historia, stan aktualny i potrzeby badań, Gdańsk, Muzeum Archeologiczne, s. 19-32.

- 2015, Rzeki w krajobrazie przyrodniczo-kulturowym wczesnośredniowiecznych Stowian pomorskich, w: S. Moździoch, K. Chrzan (red.), O rzece $i$ wodzie w życiu codziennym człowieka średniowiecza (Spotkania Bytomskie VIII), Wrocław, IAiE PAN, s. 29-51.

Chudziak W., Kaźmierczak R., Niegowski J. 2007, Niektóre problemy badawcze wczesnośredniowiecznych miejsc kultu przy śródlądowych akwenach jeziornych na Pomorzu Środkowym, w: L. Bakalarska (red.), Materiaty Konferencji Konserwatorstwa Archeologicznego zorganizowanej przez Ośrodek Ochrony Dziedzictwa Archeologicznego. Jurata (8-20 V 2005), Wigry (28-30 IX 2005), Krynica (30 XI - 3 XII), Warszawa, s. 257-270.

- 2009, Z badań nad wczesnośredniowiecznym zespołem osadniczym w Żóltem (gmina Drawsko Pomorskie) (lata 2006-2007), w: A. Janowski, K. Kowalski i S. Słowiński (red.), XVI Sesja Pomorzoznawcza, Szczecin 22-24.11.2007 r., część I: od epoki kamienia do okresu wczesnośredniowiecznego (Acta Archaeologica Pomoranica III), Szczecin, SNAP, Muzeum Narodowe w Szczecinie, Muzeum w Stargardzie, s. 367-382.

Chudziak W., Kaźmierczak R., Niegowski J., Ważny T. 2009, Ze studiów nad genezq wczesnośredniowiecznych mostów na obszarze Pomorza, Przegląd Archeologiczny 57, s. 99-131.

Ciszewski S. 1903, Ognisko. Studyum etnologiczne, Kraków, Akademia Umiejętności.

Cnotliwy E. 1982, Biatogard. Gród wczesnopolski, Koszalin, Muzeum Okręgowe w Koszalinie.

- 1999, Białogard i okolice we wczesnym średniowieczu, w: B. Polak (red.), Białogard 1299-1999. Studia z dziejów miasta, Koszalin, Muzeum Okręgowe w Koszalinie, s. 71-93.

Cnotliwy E., Nawrolski T. 1979, Grodziska wczesnośredniowieczne na Ziemi Pyrzyckiej, „Slavia Antiqua" 26, s. 143-238.

Członkowski D. 1967, Sprawozdania z ratowniczych badań archeologicznych na terenie Żydowa pow. Stawno w rejonie powstajacej elektrowni wodnej w lecie 1966 roku, w: H. Janocha i F. Lachowicz (red.), Sprawozdania z badań archeologicznych prowadzonych na terenie województwa koszalińskiego w 1966 roku, Koszalin, Muzeum w Koszalinie, s. 43-47.

- 1969 Badania wykopaliskowe grodziska Stare Borne, pow. Koszalin, „Wiadomości Archeologiczne” 34, s. 421-434.

Deptuła C. 2001, Metropolis. Z zagadnień mitu genezy stolic w Europie stowiańskiej, „Roczniki Humanistyczne" 49/2, s. 5-45.

Detelić M., Ilić M. 2006, Beli Grad. Poreklo epske formule i slovenskog toponima, Beograd Srpska Akademija Nauka i Umetnosti.

Długosz J. 1876, Jana Dlugosza Dziejów polskich ksiąg dwanaście, t. 1, Kraków, wydane nakładem Aleksandra Przeździeckiego.

Dostal B. 1975, Břeclav-Pohansko. Velkomoravsky velmožsky dvorec, Brno, Universita J.E. Purkyně.

Dulinicz M. 2000, Miejsca, które rodzq władzę (najstarsze grody stowiańskie na wschód od Wisty), w: S. Moździoch (red.), Człowiek, sacrum, środowisko. Miejsca kultu we wczesnym średniowieczu (Spotkania Bytomskie 4), Wrocław, Wydawnictwo IAiE PAN, s. 85-98. 
- 2001, Ksztaltowanie się Stowiańszczyzny Pótnocno-Zachodniej. Studium archeologiczne, Warszawa, Wydawnictwo IAiE PAN.

- 2014, Istotne problemy archeologii Pomorza (VI-IX wiek) w świetle najnowszych badań i publikacji, w: H. Paner, M. Fudziński i W. Świętosławski red., Pomorze we wczesnym średniowieczu w świetle źródet archeologicznych. Historia, stan aktualny i potrzeby badań, Gdańsk, Muzeum Archeologiczne, s. 11-17.

Filipowiak W. 1967, Stowiańskie miejsca kultowe Pomorza Zachodniego w świetle badań archeologiczno-toponomastycznych, „Przegląd Zachodniopomorski” 5, s. 5-15.

Frolík J., Smetánka Z. 1997, Archeologie na pražském hradě, Praha, Paseka.

Gieysztor A. 1982, Mitologia Stowian, Warszawa, Wydawnictwa Artystyczne i Filmowe.

Golema M. 2007, Medieval Saint Ploughmen and Pagan Slavic Mythology, „Studia Mythologica Slavica" 10 ,ss. 155-177.

Gołębiowski Ł. 1830, Lud polski i jego zwyczaje i zabobony, t. 1, Warszawa, Drukarnia A. Gałęzowskiego i Spółki.

Grodecki R. (wyd.) 1989, Anonim tzw. Gall, Kronika polska, Wrocław-Warszawa-Kraków-Gdańsk-Łódź, Ossolineum.

Hensel W. 1948, Wstęp do studiów nad osadnictwem Wielkopolski wczesnohistorycznej, Poznań, Polskie Towarzystwo Prehistoryczne.

Kajkowski K. 2017a, Obrzędowość religijna Pomorzan we wczesnym średniowieczu. Studium archeologiczne, Szczecin. Maszynopis pracy doktorskiej w posiadaniu autora.

- 2017b, O wolińskiej kacinie raz jeszcze, „Materiały Zachodniopomorskie” 12/1, s. 239-245.

Kajkowski K., Kuczkowski A., Drozd-Lipińska A. w druku, Kompleks wczesnośredniowiecznych cmentarzysk kurhanowych w obrębie gruntów wsi Jabłończ Wielki (powiat Bytów, województwo pomorskie), „Materiały Zachodniopomorskie”.

Kara M. 2009, Najstarsze państwo Piastów - rezultat przełomu czy kontynuacji? Studium archeologiczne, Poznań, Wydawnictwo IAiE PAN

Kaźmierczak R., Kowalewska B., Niegowski J. 2011, Wyniki badań archeologicznych na stanowiskach w Bobięcinie (st. 3) i Świerczewie (st. 1) w latach 2008-2009, w: M. Fudziński i H. Paner (red.), XVII Sesja Pomorzoznawcza, t. 1. Od epoki kamienia do wczesnego średniowiecza, Gdańsk, Muzeum Archeologiczne, s. 463-469.

Kiersnowski R. 1955, „Kłodona” - Kłodzień, wczesnośredniowieczna osada pomorska, „Studia Wczesnośredniowieczne" 3, s. 87-137.

Klanica Z. 1986, Religion und Kult, ihr Reflex in archäologischen Quellen, w: J. Poulík i B. Chropovský (red.), Grossmähren und die Anfänge der tschechoslowakischen Staatlichkeit, Praha, Academia, ss. $148-149$.

Knoop O. 1926, Volkssagen, Erzählungen und Schwänke aus dem Kreise Dramburg, Köslin, Hendess.

Kobyliński Z. 1997, Settlement Structures in Central Europe at the Beginning of the Middle Ages, w: P. Urbańczyk (red.), Warszawa, Wydawnictwo IAiE PAN, s. 97-114.

Kola A., Wilke G. 2006, Wczesnośredniowieczne mosty na ziemiach polskich - stan i potrzeby badań, w: W. Chudziak, S. Moździoch (red.), Stan i potrzeby badań nad wczesnym średniowieczem w Polsce - 15 lat później, Toruń-Wrocław-Warszawa, Wydawnictwo Naukowe UMK, s. 151-173.

Kolenda J. 2009, Odkrycia w warowni Milicz, „Archeologia Żywa” 44, s. 18-22.

Kowalski A.P. 2011, „Swojskość” $i$ „obcość” w kosmologicznych i socjomorficznych wyobrażeniach dawnych Stowian, w: M. Brzostowicz, M. Przybył, J. Wrzesiński (red.), Swoi i obcy w kulturze średniowiecza. Wyklady popularno-naukowe zorganizowanej w ramach VII Festiwalu Kultury Stowiańskiej i Cysterskiej w Ladzie nad Warta w dniach 18-19 czerwca 2011 roku, Poznań-Ląd, Fundacja „Unia Nadwarciańska", Muzeum Archeologiczne w Poznaniu, Starostwo Powiatowe w Słupcy, s. 15-30.

- 2013, Mit a piękno. Z badań nad pochodzeniem sztuki, Bydgoszcz, Oficyna Wydawnicza Epigram.

Kujawska A. 2012, Pozamilitarne funkcje grodów wczesnośredniowiecznych na przyktadzie Pomorza. Aspekt użytkowy i sfera symboliki, w: W. Świętosławski (red.), Ze studiów nad wczesnośredniowiecznym Pomorzem, red. Łódź, Wydawnictwo UŁ, s. 127-161.

Kurnatowska Z. 1997, Badania nad poczq̨tkami państwa polskiego. Próba bilansu, „Slavia Antiqua” 38, s. 25-38. 
Kurnatowska Z., Kara M. 2010, Wczesnopiastowskie regnum - jak powstało i jaki miało charakter? Próba spojrzenia od strony źródet archeologicznych, „Slavia Antiqua” 51, s. 23-96.

Leciejewicz L. 1989, Stowianie Zachodni. Z dziejów tworzenia się średniowiecznej Europy, Wrocław-Warszawa-Kraków-Gdańsk-Łódź, Zakład Narodowy im. Ossolińskich.

Lurker M. 1972, Der Kreis als imago mundi, "Das Münster" 25, s. 297-314.

Łosiński W. 1972, Początki wczesnośredniowiecznego osadnictwa grodowego w dorzeczu dolnej Parsęty (VII-X/XI w.), Wrocław-Warszawa-Kraków-Gdańsk, Zakład Narodowy imienia Ossolińskich, Wydawnictwo PAN.

- 1981/1982, Struktura terytorialno-polityczna Pomorza w XI stuleciu w świetle archeologii, „Slavia Antiqua" 28, s. 113-125.

- 1988, Zur Besiedlungdynamik Pommerns im frühen Mittelater (6.-11. Jh.), „Slavia Antiqua” 31, s. $1-22$.

- 2003, Poczatki wczesnośredniowiecznego Szczecina, w: E. Cnotliwy, T. Galiński, E. Wilgocki (red.), Res et fontes. Ksiega jubileuszowa dr. Eugeniusza Cnotliwego, Szczecin, Wydawnictwo SNAP, s. 69-78. 2008, Pomorze Zachodnie we wczesnym średniowieczu. Studia archeologiczne, Poznan, Wydawnictwo IAiE PAN.

Łosiński W., Olczak J., Siuchniński K. 1971, Źródła archeologiczne do studiów nad wczesnośredniowiecznym osadnictwem grodowym na terenie województwa koszalińskiego, Poznań, Wydawnictwo Naukowe UAM.

Łęga W. 1929, Kultura Pomorza we wczesnem średniowieczu na podstawie wykopalisk, cz. 1, Roczniki Towarzystwa Naukowego w Toruniu 35, s. 153-446.

Margul T. 1987, Religie jako święte przekazy. Repetytorium z teorii i fenomenologii religii dla studentów wyższych lat kierunku religioznawstwa, Kraków, Wydawnictwo UJ.

Mencej M. 2013, Simbolika obredov cirkumambulacije v tradicijskih skupnostih, „Studia Mythologica Slavica" 16, s. 125-148.

Moździoch S. 2013, Życie codzienne średniowiecznego Polaka w świetle odkryć archeologicznych czyli rozpaczliwa próba udowodnienia, że nam dzisiaj żyje się lepiej, w: M. Brzostowicz, M. Przybył, J. Wrzesiński (red.), Wioski i parafie w średniowieczu. Wyklady popularno-naukowe zorganizowane w ramach IX Festiwalu Kultury Stowiańskiej i Cysterskiej w Ladzie nad Warta w dniach 8-9 czerwca 2013 roku, Poznań-Ląd, Stowarzyszenie „Unia Nadwarciańska”, Muzeum Archeologiczne w Poznaniu, Starostwo Powiatowe w Słupcy, s. 104-128.

Niesyty M., Hoppel P. 1998, Konstrukcje obronne wczesnośredniowiecznego grodziska we Wrześnicy, stan. 7, gm. Stawno, woj. Stupskie, w: M. Dworaczyk, P. Krajewski i E. Wilgocki (red.), XII Konferencja Pomorzoznawcza (Acta Archaeologica Pomoranica I), Szczecin, Wydawnictwo SNAP, s. 167-176.

Olczak J., Siuchniński K. 1968, Źródła archeologiczne do studiów nad wczesnośredniowiecznym osadnictwem grodowym na terenie województwa koszalińskiego, t. 2, Poznań, Wydawnictwo Naukowe UAM.

- 1970, Źródła archeologiczne do studiów nad wczesnośredniowiecznym osadnictwem grodowym na terenie województwa koszalińskiego, t. 3, Poznań, Wydawnictwo Naukowe UAM.

- 1971, Źródła archeologiczne do studiów nad wczesnośredniowiecznym osadnictwem na terenie województwa koszalińskiego, t. 4, Poznań, Wydawnictwo Naukowe UAM.

- 1985, Źródła archeologiczne do studiów nad wczesnośredniowiecznym osadnictwem grodowym na terenie województwa stupskiego, t. 1, Poznań, Wydawnictwo Naukowe UAM.

- 1989, Źródta archeologiczne do studiów nad wczesnośredniowiecznym osadnictwem grodowym na terenie województwa stupskiego, t. 2, Poznań, Wydawnictwo Naukowe UAM.

Perlbach A. (wyd.) 1882, Pommerellisches Urkundenbuch (PUB), Gdańsk, brak wydawcy.

Porzeziński A. 2006, Archeologiczne badania ratownicze na stanowisku 3 w Pyrzycach, woj. zachodniopomorskie w 1993 roku, Materiały Zachodniopomorskie, Nowa Seria 2/3, s. 271-358.

Porzeziński A., Garczyński W. 2006, Archeologiczne badania rozpoznawcze w Kamieniu Pomorskim w 1958 roku, Materiały Zachodniopomorskie, Nowa Seria t. 2/3, s. 177-269.

Rączkowski W. 1998, Między programem a przypadkiem: badania osadnictwa w dorzeczu środkowej Wieprzy, w: M. Dworaczyk, P. Krajewski, E. Wilgocki (red.), XII Sesja Pomorzoznawcza, Szczecin 23-24 października 1997 r. Materiały (Acta Archaeologica Pomoranica I), Szczecin, SNAP, Muzeum Narodowe w Szczecinie, Muzeum w Stargardzie, s. 157-166. 
- 2008, Antropogeniczne formy krajobrazowe powstałe w pradziejach i wczesnym średniowieczu w dorzeczu środkowej Wieprzy, „Landform Analysis” 7, s. 143-153.

Rębkowski M. 2016, Ecclesia sancti Nicolai w Lubinie. Kościót grodowy z doby pomorskich misji Ottona z Bambergu, w: M. Rębkowski (red.), Kościoły w dobie chrystianizacji, Szczecin, Wydawnictwo IAiE PAN, s. 225-238.

Rębkowski M., Kiarszys G. 2014, O niektórych problemach badawczych zwiazanych ze średniowieczna Cedynia, w: P. Migdalski (red.), Civitas Cedene. Studia i materiały do dziejów Cedyni, t. 1, Cedynia, Terra Incognita, Muzeum Regionalne w Cedyni, s. 101-117.

Skrzypek I. 1998/1999, W sprawie „Belbuka”, w: E. Choińska-Bochdan, M. Kwapiński, H. Paner, A. Szymańska (red.), Z Otchłani Wieków Pomorza Gdańskiego. Zeszyt okazjonalny dla upamiętnienia Tysiaclecia Gdańska. 997 urbs Gyddanyze - 1997 Gdańsk, Gdańsk, Muzeum Archeologiczne, s. $166-173$.

Slivka M. 2004, K náboženskému synkretizmu v strednej Európe, w: R. Kožiak i J. Nemeš red., Pohanstvo a krest'anstvo. Zbornik z konferencie usporiadanej 5.-6. II. 2003v Banskej Bystrici, Bratislava, Chronos, s. 147-162.

Słupecki L.P. 1994a, Problem stowiańskich światyń, „Slavia Antiqua” 35, s. 47-67.

- 1994b, Slavonic Pagan Sanctuaries, Warszawa, Wydawnictwo IAiE PAN.

Swienko H. 1983, Magia w życiu człowieka, Warszawa, Młodzieżowa Agencja Wydawnicza.

Szultka Z. 2014, Światynia na Rowokole i jej funkcje, Słupsk, Wydawnictwo AP.

Szymański W. 2015, Refleksje na temat początków grodów u Stowian, w: M. Żurek, M. Krasna-Korycińska (red.), Grody średniowiecznego Mazowsza. Księga poświęcona pamięci Marka Dulinicza, Warszawa-Zielona Góra, Wydawnictwo IA UKSW w Warszawie, Wydawnictwo IAiE PAN, s. 31-38.

Třeštík D. 1997, Počátki Přemyslovců. Vstup Čechů do dějin (530-935), Praha, Lidové noviny.

Urbańczyk P. 2012, Mieszko I tajemniczy, Warszawa, Wydawnictwo FNP.

- 2013, Jak powstawaty państwa w czasach ksztaltowania się monarchii wczesnopiastowskiej, w: J. Banaszkiewicz, M. Kara, H. Mamzer (red.), Instytucja ,wczesnego państwa” w perspektywie wielości i różnorodności kultur, Poznań, Wydawnictwo IAiE PAN, s. 317-329.

- 2014, Archeologia grodzisk w badaniach wczesnych państw Europy Środkowej, w: Chrzan, K. Czapla, S. Moździoch red., Funkcje grodów w państwach wczesnośredniowiecznej Europy środkowej. Społeczeństwo, gospodarka, ideologia, Wrocław-Głogów, Wydawnictwo IAiE PAN, PWSZ w Głogowie, s. 27-36.

Wielgosz Z. 2006, Pogranicze wielkopolsko-zachodniopomorskie we wczesnym średniowieczu, Poznań, Wydawnictwo IH UAM.

Wiszewski P. 2012, Different visions for different publicity? The early Piasts communication strategy (c. 962-1058), w: S. Moździoch i P. Wiszewski red., Consensus or Violence? Cohesive Forces in Early and High Medieval Societies (9th-14th c.) (Interdisciplinary Medieval Studies I), Wrocław, Wydawnictwo IAiE PAN, s. 315-331.

Wrzesiński J., Kara M. 2016, Stratygrafia, chronologia oraz wybrane zagadnienia socjotopografii najstarszego grodu na Ostrowie Lednickim, w: Z. Kurnatowska, A.M. Wyrwa (red.), Ostrów Lednicki. Rezydencjalno-stoleczny ośrodek pierwszych Piastów, Warszawa: Wydawnictwo IAiE PAN, s. 72-105. 